\title{
Caesar's British Expedition: What are the Real Intentions Behind His Two Expeditions?
}

\begin{abstract}
Zhejun Zhang, *
${ }^{1}$ Western Reserve Academy, Hudson, Ohio, the United States

*Corresponding author. Email: ZhangZ22@wra.net

ABSTRACT

This paper aims to discuss the real intention behind Caesar's two British expeditions and the evidence against the conquest theory. In Commentarii De Bello Gallico, Caesar claimed that he invaded Britain because he would like to teach the Britons a lesson for aiding the Gauls. Most modern scholars disagree that Caesar's true intention is what Caesar had said, so they came up with their own theories. Ranzani said Caesar's expedition is for glory, while Deutsch argues that Caesar's expeditions are for pearls. Mitchell suggests that Caesar went to Britain for tin, while Ranzani, Schadee, Raaflaub, and Riggsby all came up with the theory of Caesar's military and political gains. Brady is one of the few scholars who believe in what Caesar had said - to punish the Gauls. Moreover, Brady also considers Caesar's expeditions a success since he does not think Caesar's true goal is to conquer Britain.
\end{abstract}

Keywords: Caesar's British Expedition, Real intention, Conquest theory

\section{INTRODUCTION}

The modern scholars proposed four mainstream theories regarding the intentions behind Caesar's two British expeditions reviewed in this paper -- for personal glory, for pearls, for strategic resources, and political gains. While Caesar had claimed that he launched his British expeditions to punish the Gauls, few scholars believed him. Most modern scholars suggest that there are additional reasons behind Caesar's British expeditions. In this paper, four pieces of evidence will also be provided against the conquest theory. Even though some modern scholars consider Caesar's expeditions' failures due to his failure in conquering the island, it is more likely that Caesar did not aim to conquer Britain in the first place.

\section{CAESAR'S COMMENTARII DE BELLO GALLICO: THE INTENTIONS HE CLAIMED}

\subsection{Introduction to Caesar's Two Invasions}

On August 26, 55 BC, Julius Caesar first stepped foot on the island of Britain. Caesar fought in Britain for ten weeks before ending his expedition and retreating to Gaul for winter with two Roman legions at his side, as shown in Figure 1 and Figure 2.

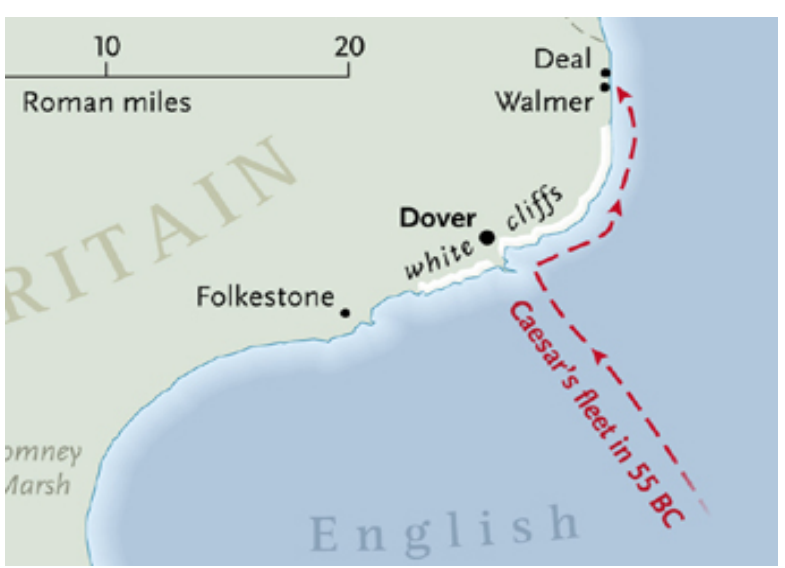

Figure 1. Caesar's Fleet Across the Channel during His First Invasion in 55 BC [1].

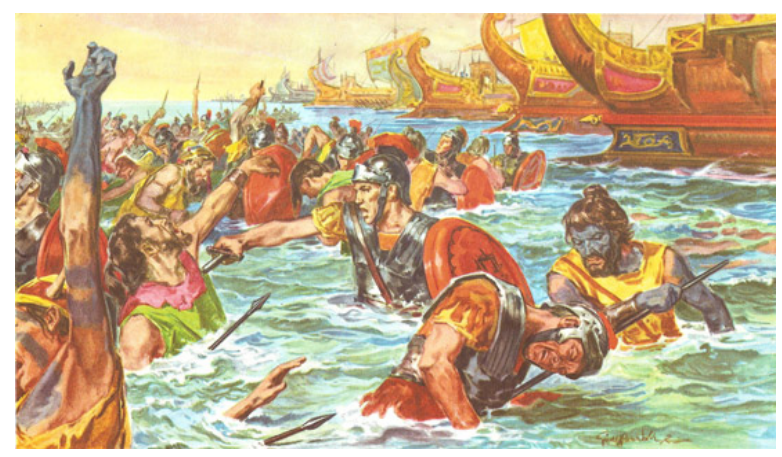

Figure 2. Darling, D. Caesar in Britain [2]. 
Caesar's second expedition started the following year, on July 6, $54 \mathrm{BC}$. This time, he brought five legions and 2,000 cavalries. Fighting through Southern Britain, he crossed the river Thames and forced the British leader Cassivellaunus into surrender. Caesar then imposed peace treaties on the Britions before finally returning to Gaul on September 3, 54BC (Figure 3 \& Figure 4).

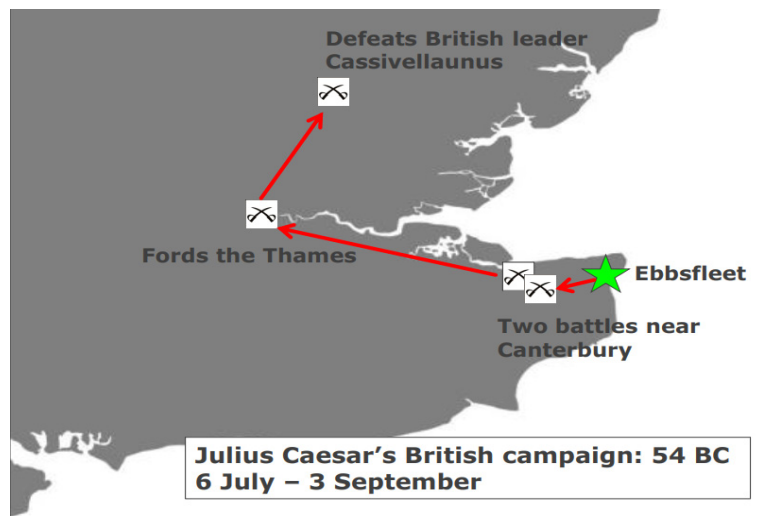

Figure 3. Julius Cæsar's British Campaign: 54 B.C., 6 July to 3 September [3].

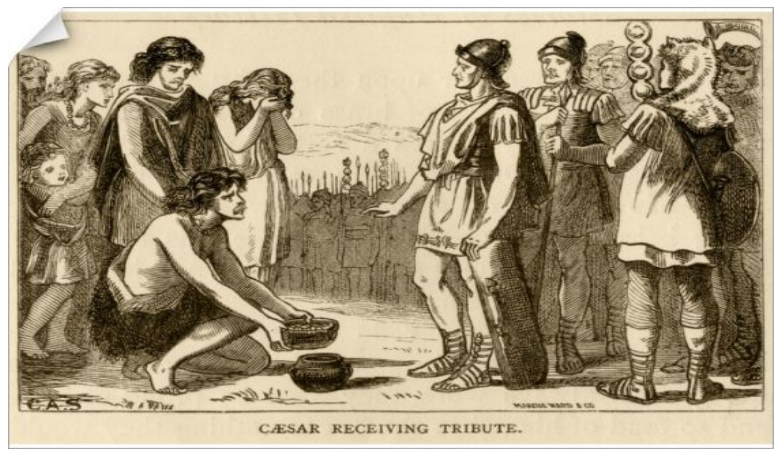

Figure 4. Julius Caesar Receiving Tribute. Marcus Ward \& Co, London \& Belfast [4].

\subsection{Introduction to Caesar's Two Invasions}

As what Caesar had written in Commentarii De Bello Gallico, "During the short part of summer which remained," he was "resolved to proceed into Britain" [5]. "Because he discovered that in almost all the wars with the Gauls, succors had been furnished to our [Caesar's] enemy from that country," Caesar knew that he had to launch an expedition into the mysterious island on the edge of the Roman world to teach the Britons a lesson. "And even if the time of year should be insufficient for carrying on the war," Caesar still thought that it would be wise to land on Britain and "saw into the character of the people, and got knowledge of their localities, harbors, and landing-places, all which were for the most part unknown to the Gauls." Since he was unable to learn "the size of the island", "how numerous were the nations which inhabited it", "what customs they used", "what harbors were convenient for a great number of ships" from the merchants he had gathered, so he had not much information about Britain before his first expedition [5]. Of course, there is a possibility that the merchants were lying to Caesar about them not knowing this information since they are trading with the Britons, and they might want to protect the source of their richness.

\subsection{Summary of Caesar's Claim}

Caesar claimed that he invaded Britain because he discovered that the British had aided the Gauls during his wars against them. Since the island is on the edge of the Roman world, the Romans have no understanding. Therefore, Caesar also claimed that he launched his expedition to better know the island's people and the island itself.

\section{COUNTER ARGUMENTS OF MODERN SCHOLARS REGARDING THE REAL MOTIVATION BEHIND CAESAR'S EXPEDITIONS}

\subsection{Introduction}

Despite Caesar's statement in his book Commentarii de Bello Gallico, most modern scholars do not believe or do not completely agree with what Caesar had said. While some scholars believe in what Caesar had claimed and considered Caesar's main goal to punish the British tribes [6], which Caesar succeeded in doing, most scholars had different views on Caesar's true intention when he invaded Britain. The debate is still heated to this day.

\subsection{Views and Reasonings of Modern Scholars}

Modern scholars suggest four different mainstream assumptions regarding the reason why Caesar launched his British expeditions.

The first theory is Caesar's glory. As Britannia is at the very edge of the Roman world, the first Roman commander to lead expeditions on the island is honorable. This is one of the many "first" titles in Roman history. Just as Ranzani said, to justify his invasions, Caesar needed to "conceal his main reason for fighting the Britons", and his main reason was for "personal glory" [7].

The second theory argues that the reason behind Caesar's invasions is for pearls. As Deutsch argued in his article, though Caesar "may have cared for the pearls", his primary intention was not to "secure it" [8]. Caesar "may have cared for the pearls", but he did not launch the invasion just for the pearls [8]. Ranzani points out that Caesar's main reason for the invasion is probably for glory, instead of pearls - pearls are just secondary intentions for Caesar's personal gain [8]. 
The third theory is for strategic resources, such as tin. As an essential ingredient in the producing process of bronze, controlling tin mines will make the controller rich. Other precious metals - such as silver and gold - are good reasons for Caesar to invade Britain. Mitchell stated in his paper, "Tin is also found in islands which lie beyond the ocean opposite to Spain" [9]. This proves that the Romans knew that there are tin mines on the British Isles, making it possible for "finding strategic resources like tin" to be a reason behind Caesar's two invasions.

The fourth and last theory is for Caesar's own political and military gain. This theory is the most agreed-upon theory among modern scholars. Caesar needed to continue his conquests after conquering Gaul to "maintain his political influence in Rome" [7]. Shandee agreed by stating that Caesar needed his two planned invasions to help him "maintain the upper hand over his political opponents" [10] in the Roman senate. Raaflaub, a Swiss historian, supported the theory by stating that Caesar had always tried to "sought support outside the senate" [11]. Indeed, Caesar had "a chance not just to win glory" [12] but to get military and political gains as well.

\subsection{Summary}

Although there are many different theories regarding the true reason behind Caesar's invasions, one thing is for certain - modern scholars do not consider "punishing the Britons" the only reason behind Caesar's invasions. Instead, personal Glory, pearls, strategic resources, and military and political gains are all considered possible reasons behind the two invasions. We may never know whether these theories are true reasons for the two invasions, but these theories can help us get closer to the answer.

\section{CAESAR'S BRITISH EXPEDITIONS: CONQUEST OR NOT?}

\subsection{Introduction}

Whether Caesar aimed to conquer Britain during the two invasions had been debated throughout modern history. Some scholars, such as Brady, believe that Caesar's true intention was never to conquer Britain but to simply "punish the Britons," as claimed in his Commentarii. Other scholars had a different argument. They argue that Caesar's invasions are for military conquest - what Claudius had accomplished in $43 \mathrm{AD}$, and he completely failed. The disagreement between these two arguments leads to another question: Is Caesar a successful military commander during British Expeditions?

\subsection{Counter Arguments for the Conquest Theory}

In Brady's Caesar and Britain, he talked about how Caesar should not have planned to conquer Britain. The first evidence Brady presented is what Caesar had said himself. Caesar said that he planned to winter in Gaul rather than his usual place that year. This means that Caesar's invasion of 55-54 B.C. should be "probably no more than a demonstration or a reconnaissance in force" [13]. The second evidence Brady mentioned is the size of Caesar's army. Caesar had five legions and 2,000 gallic cavalries at the time, which Brady said should be " 22,000 at most" [13]. To conquer a single tribe, the Treveri, Caesar took with him four legions and 800 horsemen. So, according to Brady, five legions and 2,000 gallic cavalries are not prepared for Caesar to conquer a large and unknown island at the time.

The third evidence Brady used to support his argument is the fact that Caesar knew that he conquers Gaul is not solidified. The gallic tribes he conquered were still rebelling against him, so he knew that he couldn't leave the province for too long. The fourth evidence Brady brought up is that Caesar had won in his war against the British tribes. The capture of the stronghold Oppidum broke the resistance of the Britons, giving Caesar victory over the Britons. If Caesar was actually aiming for conquest, he should have left troops in Briton to consolidate his conquest. However, Caesar did not leave any troops behind in Briton, suggesting that he did not want to conquer Britain at the time.

\subsection{Conquest or Not}

Although Caesar could have been aiming for conquest during either of his two invasions of Britain, it is more likely that he was not going for conquest in the first place. Caesar landed in August, near winter, during his first invasion. This suggests that Caesar was not planning for a long campaign. The size of Caesar's army also suggests that Caesar's invasion is not going for the conquest of Britain. The need to stabilize rebelling gallic tribes further stops Caesar from going for a complete conquest in Britain. Even after his victories, Caesar did not leave any troops behind to consolidate his gains, further suggesting that Caesar was not going for military conquest. So even though Caesar could have conquered Britain, he most likely did not go for conquest in the first place.

\section{CONCLUSION}

This paper reviews four main theories regarding the motives behind Caesar's two invasions of Britain and the four supportive shreds of evidence against the conquering theory for Caesar's expeditions. In his Commentarii de Bello Gallico, Caesar claimed that his true motive behind 
his two invasions of Britain was because he needed to punish the Britons for aiding the Gauls during his Gallic Wars. However, most modern scholars do not believe it. Modern scholars think there are other motives for Caesar to launch the two invasions - most notably, for personal glory, pearls, strategic resources, and military and political gains. Even though some scholars consider Caesar's two invasions a failure due to him failing to conquer the island, it depends on whether Caesar aimed for conquest for his two invasions. Four pieces of evidence support the argument against the conquest theory - the date that Caesar launched the invasion, the size of his army, the risk of losing his gains in his gallic conquest, and the fact that he left no troops behind after he won his victory war against the Britons. Due to the four pieces of evidence, it is more likely for Caesar's two invasions to be a success because he is not aiming for a conquest. Even though we may never know the truth behind the motives of Caesar's two invasions or the actual aim for Caesar's two expeditions, through these theories proposed by modern scholars, we are getting closer and closer to the truth.

\section{REFERENCES}

[1] Information from skyandtelescope.org/pressreleases/astronomers-re-date-caesars-invasion-ofbritain/

[2] Information from www.daviddarling.info/encyclopedia_of_history/C /Caesar_in_Britain.html.

[3] Information from www.dealpier.uk/caesar.html

[4] Information from

www.fineartstorehouse.com/famous-influentialpeople/famous-military-leaders-julius-caesar-100bc-44-bc/julius-caesar-receiving-tribute21051437.html.

[5] Caesar, Julius. Commentarii De Bello Gallico. Translated by W. A. McDevitte and W. S. Bohn, www.stcharlesprep.org/01_parents/oneil_j/Useful $\%$ 20Links/AP\%20Latin\%20Assignments/HW/The \%20Gallic\%20Wars.pdf. Accessed 25 Feb. 2021.

[6] Nolan, Roger. "The Campaign in Britain -- Success or Failure?" Julius Caesar's Invasion of Britain: Solving a 2000-year-old Mystery, 2018, pp. 97-102.

[7] Ranzani, Giacomo Amilcare Mario. "The rebellion of Dumnorix and the second expedition to Britain: events manipulation in Caesar's "De bello Gallico" V 1-7." Maia-rivista Di Letterature Classiche 70 (2018): 461-476.

[8] Deutsch, Monroe E. "Caesar and the Pearls of Britain." The Classical Journal, vol. 19, no. 8, May
1924, pp. 503-05. JSTOR, www.jstor.org/stable/3288779. Accessed 30 Jan. 2021.

[9] Mitchell, S. 1983: Cornish Tin, Julius Caesar and the Invasion of Britain.

[10] Schadee, Hester. "Caesar's Construction of Northern Europe: Inquiry, Contact and Corruption in 'De Bello Gallico."' The Classical Quarterly, ns, vol. 58, no. 1, May 2008, pp. 158-80. JSTOR, www.jstor.org/stable/27564130. Accessed 30 Jan. 2021.

[11] Raaflaub, Kurt A. "Caesar, Literature, and Politics at the End of the Republic." The Cambridge Companion to the Writings of Julius Caesar, 28 Dec. 2017, pp. 13-28, doi:10.1017/9781139151160.002. Accessed 30 Jan. 2021.

[12] Riggsby, Andrew M. "The Politics of Geography." The Cambridge Companion to the Writings of Julius Caesar, 28 Dec. 2017, pp. 68-80, doi:10.1017/9781139151160.006. Accessed 30 Jan. 2021.

[13] Brady, S. G. "Caesar and Britain." The Classical Journal, vol. 47, no. 8, May 1952, pp. 305+. JSTOR, www.jstor.org/stable/3293057. Accessed 30 Jan. 2021. 